\title{
Results of the Quarterly Tritium Survey of Fourmile Branch and its Seeplines in the F- and H-Areas of SRS: September 1993 (U)
}

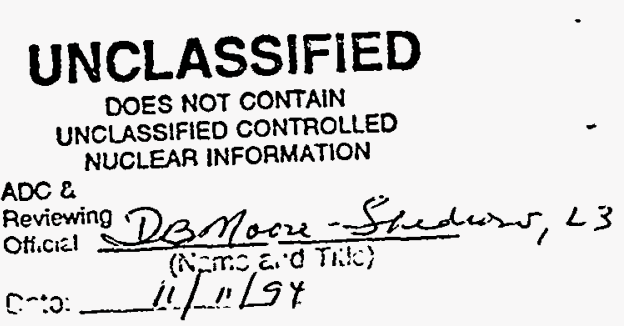




\section{DISCLAIMER}

This report was prepared as an account of work sponsored by an agency of the United States Government. Neither the United States Government nor axy agency thereof, nor any of their employees, makes any warranty, express or implied, or assumes any legal liability or responsibility for the accuracy, completeness, or usefulness of any information, apparatus, product, or process disclosed, or represents that its use would not infringe privately owned rights. Reference herein to any specific commercial product, process, or service by trade name, trademark, manufacturer, or otherwise does not necessarily constitute or imply its endorsement, recommendation, or favoring by the United States Government or any agency thereof. The views and opinions of authors expressed herein do not necessarily state or reflect those of the United States Government or any agency thereof.

This report has been reproduced directly from the best available copy.

Available to DOE and DOE contractors from the Office of Scientific and Technical Information, P.O. Box 62, Oak Ridge, TN 37831; prices available from (615) 576-8401.

Available to the public from the National Technical Information Service, U.S. Department of Commerce, 5285 Port Royal Road, Springfield, VA 22161. 


\section{DISCLAIMER}

Portions of this document may be illegible in electronic image products. Images are produced from the best available original document. 


\section{Results of the Quarterly Tritium Survey of Fourmile Branch and its Seeplines in the F- and H-Areas of SRS: September 1993 (U)}

K.L. Dixon, V.A. Rogers, and B.B. Looney

$-$

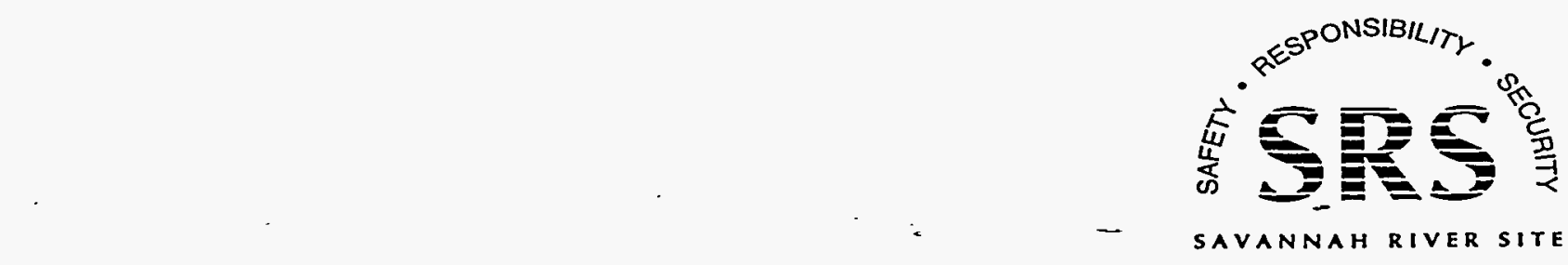

Prepared for the U.S. Department of Energy under contract no. DE-AC09-89SR18035 


\title{
Results of the Quarterly Tritium Survey of Fourmile Branch and its Seeplines in the F- and H-Areas of SRS: September 1993
}

\author{
K. L. Dixon, V. A. Rogers, and B. B. Looney
}

\begin{abstract}
The Environmental Sciences Section (ESS) established a quarterly monitoring program of the Fourmile Branch (FMB) seepline down gradient from the F- and H-Area seepage basins. The program surveys and tracks changes in tritium, specific conductivity, and $\mathrm{pH}$ for the seepline water. Measurements from the sixth quarterly survey (September 1993) showed higher tritium and conductivity measurements and higher $\mathrm{pH}$ values $(\mathrm{pH} 5-6)$ than measurements from previous studies. Increased tritium concentrations and conductivity values, as compared to previous surveys, were attributed to decreased rainfall prior to the sampling event. However, overall results of the tritium survey and stream monitoring data (Looney et al., 1993) suggest that the tritium plume is flushing from the FMB system.
\end{abstract}

\section{Executive Summary}

In September 1993, the Environmental Sciences Section (ESS) surveyed the Fourmile Branch (FMB) seepline down gradient from the F- and $\mathrm{H}$-Area seepage basins for tritium, specific conductivity, and $\mathrm{pH}$. The survey was the sixth of eight quarterly surveys for monitoring the movement of contaminants from the basins since closure. Surface-water samples were collected from 60 locations along the seepline and from three locations along FMB. The seepline locations included 22 in F Area, 22 in H Area, and 16 on the seepline south of 643-E, which is a decommissioned area in the Solid Waste Disposal Facility. Forty four locations were sampled in 1989 by the Savannah River Laboratory (now the Savannah River Technology Center) as part of an extensive characterization study (Haselow et al., 1990). ESS found that tritium activities in the F-Area seeplines in September 1993 were not significantly lower than the activities measured by Haselow et al. (1990). Tritium activities measured in $\mathrm{H}$ Area were significantly lower than those measured by Haselow et al. (1990), but were elevated compared to recent sampling events. Increases in tritium activities were attributed to below normal rainfall in the months prior to the September 1993 sampling event. The lack of rainfall, which decreased recharge to the shallow groundwater, modified the trajectory of the tritium plume. Theoretically, lower discharge shifts the plume upward and the arrival point away from FMB and toward the seepage basins. Therefore, the more concentrated portion of the plume moved within the sampling zone at the seepline intercept. This produced increased tritium concentrations at the seepline intercepts at F- and $\mathrm{H}$-Area seeplines.
Previous sampling events consistently show a declining trend in tritium concentrations at the F-Area seepline. Total tritium fluxes to the wetlands and FMB steadily declined since basin closure (Looney et al., 1993) and overall results from the tritium survey support this finding. Differences in tritium concentrations measured at seepline sampling locations from one sampling event to the next represent seasonal variability and changes due to the flushing of the plume from the wetland system. Conclusions about tritium fluxes to the wetlands and FMB should consider the complexity of the groundwater system and should be based on long-term surface water, seepline, and groundwater monitoring data, not on quarterly changes in concentrations at seepline monitoring stations.

September 1993 conductivity measurements exhibited the same trends as tritium activities in $\mathrm{F}$ and $\mathrm{H}$ Areas. Concentrations of hydrogen ions also decreased in both areas, indicating that conditions are changing from strongly acidic to slightly acidic (pH $5-6$ ), which is normal for these types of wetlands. Aluminum concentrations measured along the seepline in 1989 (Haselow et al., 1990) were high enough to be potentially toxic to plants. Increases in $\mathrm{pH}$ (to about neutral) will reduce the solubility of aluminum and thereby reduce it as a possible source of plant toxicity. Concentrations of aluminum, as well as other metals, measured along the seepline in July 1992 were substantially lower than 1989 concentrations reflecting the increase in $\mathrm{pH}$ (Dixon and Rogers, 1993e). Field observations revealed that vegetation in most stressed areas is recovering. 
The seepline south of 643-E, along a tributary of FMB, is influenced by tritium migrating from the burial grounds. The tributary (old F-Area effluent ditch) is a natural drainage used to discharge effluent from F-Area Separations prior to the construction of the engineered effluent canal. September 1993 tritium activities ranged from 35 to $947 \mathrm{pCi} / \mathrm{ml}$ on the east side of the drainage and from 169 to $59400 \mathrm{pCi} /$ $\mathrm{ml}$ on the west side. The tritium concentration measured in the stream of the natural drainage was $17100 \mathrm{pCi} / \mathrm{ml}$. Results suggest that the tritium outcrop area has been delineated by the sampling locations established on the west side of the drainage. Conductivity and $\mathrm{pH}$ measurements taken on both sides of the drainage were similar and within the range of normal values for this type of wetland. The low conductivity values measured along the drainageway suggest that the tritium plume outcropping in the area emanates from 643-E because wastes introduced into 643-E contained low levels of salt ions compared to the waste in the F- and $\mathrm{H}$ Area basins.

\section{Introduction}

SRS seepage basins in the F and $\mathrm{H}$ Area received lowlevel radioactive-waste effluent from the chemical separation processes in the general separation areas. The basins retained the effluent to delay its release to the environment. The waste effluent consisted principally of sodium hydroxide, nitric acid, low levels of various radionuclides, and some metals (Killian et al., 1985a and 1985b). Discharges of tritiated water to the seepage basins accounted for most of the radioactivity (Fenimore and Horton, 1972).

$\therefore$ In 1988 and 1989, the Savannah River Laboratory (now the Savannah Rivier Technology Center) conducted an extensive study aimed at characterizing the shallow groundwater outcropping into Fourmile Branch (FMB) and its associated seepline (Haselow et al., 1990). As a part of this study, Haselow et al. (1990) surveyed for tritium, $\mathrm{pH}$, and conductivity. Researchers found low $\mathrm{pH}$ levels and elevated conductivity and tritium values along the seeplines. They determined that contaminants leaching from the F- and H-Area seepage basins are impacting the wetlands below the basins. SRS stopped discharges to the seepage basins in 1988 and capped and sealed the basins in 1990 to reduce the release of contaminants. Scientists hypothesized that after eliminating the contaminant source, annual rainfall and natural groundwater flow would flush the remaining contaminant plume out of the shallow groundwater over time. After the contaminant plume in the shallow groundwater is flushed out, the wetland systems below the basins should recover.

To investigate this hypothesis, a quarterly sampling program was established. ESS sampled 44 seepline locations (sampled by Haselow et al., 1990) for tritium, pH, and specific conductivity. The Haselow et al. (1990) results established the baseline to which the results from the quarterly sampling program are compared. They were chosen as the baseline because they are the only data available that were collected when the basin discharges were discontinued. The Haselow et al. (1990) data should be representative of conditions during normal operation. This sampling program is intended to complement semiannual sampling of the seepline for selected Resource Conservation Recovery Act, Appendix IX, characterization, which began in July 1992. A report summarizing results from the semiannual sampling program is complete (Dixon and Rogers, 1993e).

The Environmental Protection Department expressed concern about possible seepage of tritium and other contaminants from 643-E. To investigate this possibility, several sampling locations on the H-Area seepline south of 643-E were established and incorporated into the quarterly sampling plan.

\section{Methods}

ESS conducted the sixth round of sampling in the quarterly tritium survey in September 1993. Sampling locations were selected that, according to 1989 data, exhibited high and low values for the three variables of concern. Attempts were made to establish even ground coverage along both seeplines. ESS collected 60 samples from the seeplines in F and H Area: 22 from the F-Area seepline, 22 from the $\mathrm{H}$-Area seepline, and 16 from the FHB seepline south of 643-E. ESS also collected samples from three locations on FMB. Figures 1 and 2 show the sampling locations.

Prior to sampling for the first quarter, the Health Protection Department (HPD) collected soil samples from several locations along both seeplines and monitored them for gamma radioactivity. HPD did not detect gamma radiation. Based on the HPD findings, ESS selected rubber boots and disposable rubber gloves as protective clothing to prevent dermal contact with seepline water during sampling operations.

Seepline sampling locations were previously marked and labeled with PVC stakes. Water samples were collected within a 3-feet radius of the PVC stake by boring a hole into the soil with a 3.5-inch soil auger until water was reached. To collect water for tritium analysis, polyethylene sample containers $(25 \mathrm{ml})$ were dipped into the water until full and then capped. The outside of each container was rinsed with deionized water and sealed in a small polyethylene bag to minimize the possibility of contamination. 
The small bags were sealed in a large polyethylene bag. The Environmental Monitoring Section (EMS) performed tritium analysis. EMS counted $5 \mathrm{ml}$ aliquots for $20 \mathrm{~min}$ utes, which yielded a lower detection limit of $1.3 \mathrm{pCi} / \mathrm{ml}$ (WSRC-3Q1-4, 1992).

ESS measured specific conductivity and $\mathrm{pH}$ in situ with conductivity and pH electrodes (WSRC-L 14.1, 1992a and 1992b). The electrodes were rinsed with deionized water after each sampling. All sampling equipment was thoroughly rinsed with water at the end of each day.

\section{Results and Observations}

Concentrations of variables measured at seepline sampling locations fluctuate throughout the year. Climate, especially rainfall, influences measured concentrations. Seepline measurements are made on water collected from fixed locations at the distal end, or toe, of the contaminant plume. Because the plume is dynamic (i.e., influenced by weather and other activities in the area) seepline monitoring is sensitive to long-term changes and seasonal/transient influences. Groundwater flow paths in F- and H-Area are complex, as illustrated in Figure 3. Recharge to the groundwater is primarily due to infiltration of rainwater (rainfall minus runoff and evapotranspiration). Groundwater then moves laterally to FMB and its tributaries. As the water travels toward the stream, additional infiltration forces up-gradient water deeper. Near the stream, the flow lines rise to the surface, emerging between the seepline and the stream, which acts as the groundwater "drain". -This classic vertical trajectory, a path curving downward near the groundwater divide and then moves upward into draining surface water, is shown as flow lines on Figure 3.

Figure 3(a) shows the flow lines without contaminated water from the seepage basins and Figure $3(\mathrm{~b})$ shows the addition of contaminated flow lines from the basins when they were operating. The theoretical plume geometry is clearly confirmed by the real vertical profile of the F-Area Seepage Basin plume based on the detailed grid wells available in the 1970 s (Looney et al., 1993). Changes in the water balance in the area influence the flow velocity and tend to move the plume deeper or shallower and cause the location of the contaminated water to move. This is especially important to data interpretation if the "toe" of the plume is shifting relative to the fixed sample stations. Figure 4 summarizes the expected changes in the plume based on a range of transient activities. Increased rainfall (or other activities that increase infiltration, such as harvesting trees) results in increased plume velocity and movement of the plume downward and away from the seepline. This results in decreased contaminant concentrations as measured at the seepline sampling locations.
Reduction in infiltration results in decreased plume velocity and movement of the plume upward and closer to the seepline. This results in increased contaminant concentrations as measured at the seepline sampling locations.

Low rainfall for a few months prior to sampling results in increased constituent concentrations, and high rainfall results in decreased constituent concentrations in the shallow groundwater at the seepline intercept. Rainfall measured at the SRS weather station in F-Area from January through September 1993 was $112.62 \mathrm{~cm}$. From 1960 to 1991, the average rainfall measured in F-Area from January through September was $102.67 \mathrm{~cm}$. This indicates that average rainfall in $\mathrm{F}$ and $\mathrm{H}$ Areas was above normal for the period; however, the surplus in rainfall occurred primarily in the first three months of the year. From January through March, rainfall measured in F-Area was $21.18 \mathrm{~cm}$ in excess of the long-term average for the period. From April through September, rainfall measured in F-Area was 18.44 -. $\mathrm{cm}$ below the long-term average.

Figure 5 shows a comparison of 1993 rainfall to the longterm average (1960-1991) from January through September. This figure shows that, except for June and September, rainfall was substantially lower than the long-term average. Rainfall totals for June and September were heavily influenced by brief, intense storms. Storms of this nature commonly yield large amounts of rainfall over short periods of time with high runoff and low infiltration. This type of event would not be expected to ameliorate the effects of several months of below average rainfall.

As a result of the below average rainfall observed in the area prior to the September 1993 sampling event, contaminant concentrations would be expected to increase at sampling locations closer to the basins and to decrease at locations farthest away. This occurs because decreases in infiltration cause the toe of the plume to migrate upwards through the soil profile and the arrival point to move away from FMB and towards the basins.

Figures 6 through 11 show comparisons of 1989 and June and September 1993 tritium, conductivity, and $\mathrm{pH}$ measurements. Data for the first five surveys can be found in Dixon and Rogers (1992, 1993a, 1993b, 1993c, and 1993d). Figures 12 through 14 show the data for the locations on the seepline south of 643-E in H Area. These sampling locations have the identification prefix, "FHB". Figures 15 through 17 show the data for the Fourmile Branch locations, which also have the identification prefix "FHB". 


\section{F- and $\mathrm{H}$-Area Seepline Tritium Measurements}

\section{F Area}

September 1993 tritium values in the F-Area seepline ranged from 12 to $17,800 \mathrm{pCi} / \mathrm{ml}$ (see Table 1 and Figure 6). In

F Area, water was attained within approximately 18 inches of the soil surface at all of the sampling locations, except FSP235. Location FSP235 was listed as dry and no measurements were made. Six of the remaining 21 sampling locations had above-background tritium activities that exceeded the 1989 measurements by more than $10 \%$. The tritium activity of $17,800 \mathrm{pCi} / \mathrm{ml}$ measured at FSP035 exceeded the maximum value of $14,000 \mathrm{pCi} / \mathrm{ml}$ recorded in 1989 for the F-Area seepline. In 1989, maximum tritium activities $(14,000 \mathrm{pCi} / \mathrm{ml})$ were measured at FSP014 and FSP034 and the activity measured at FSP035 was $11,000 \mathrm{pCi} / \mathrm{ml}$.

As with data from previous quarters, a Wilcoxon signedrank test was conducted to compare September 1993 tritium activities to March 1989 activities. The Wilcoxon signed-rank test uses the sign and the magnitude of the rank of the differences between pairs of measurements to compare nonparametric data (Daniel, 1978). This test was chosen because it allows comparisons of paired data without assumptions of normality. The results showed that the September 1993 concentrations were not significantly less $(P=0.205)$ than the 1989 concentrations.

\section{H Area}

Tritium values in the H-Area seepline ranged from 124 to $15,500 \mathrm{pCi} / \mathrm{ml}$ (see Table 2 and Figure 7). Water in H Area was attained within approximately 18 inches of the soil surface at all of the sampling locations, except HSP013. Location HSP013 was listed as dry and no measurements were made. Of the remaining 21 sampling locations, four had above-background tritium activities that exceeded the 1989 measurements by more than $10 \%$. No tritium activities exceeded the maximum value of $24,000 \mathrm{pCi} / \mathrm{ml}$ measured in 1989.

As with data from previous quarters, a Wilcoxon signedrank test was conducted to compare September 1993 tritium activities to March 1989 activities. The Wilcoxon signed-rank test uses the sign and the magnitude of the rank of the differences between pairs of measurements to compare nonparametric data (Daniel, 1978). This test was chosen because it allows comparisons of paired data without assumptions of normality. The results showed that the September 1993 concentrations were significantly less $(P=0.002)$ than the 1989 concentrations for H-Area. Even though tritium activities increased at several locations, compared to previous sampling events, they remained substantially lower than those measured in 1989 at most locations.

Figures 6 and 7 show that for the September 1993 sampling event, the tritium activity at most locations in F- and H-Area either increased or remained relatively unchanged, compared to previous sampling events. These results, while expected, contrast those observed in the five previous sampling events. Previous sampling events consistently showed a declining trend in tritium concentrations at the F-and H-Area seeplines. During that period, rainfall amounts were near normal and the toe of the tritium plume was outcropping close to FMB. This resulted in elevated tritium concentrations at the locations closest to FMB. Prior to September 1993, the below average rainfall caused the plume to move upward through the soil profile while the toe of the plume moved back towards the seepage basins and the seepline intercept. Therefore, tritium concentrations at most locations (particularly those closest to the basins) increased considerably. When rainfall returns to normal levels, the plume should move deeper in the soil profile and again outcrop closer to FMB. When this occurs, tritium concentrations at the seepline should return to levels typically measured in the past. It is important to note that total tritium fluxes to the wetlands and FMB steadily declined since basin closure (Looney et al., 1993) and that overall results of the tritium survey support this finding. Differences in tritium concentrations measured at seepline sampling locations from one sampling event to the next represent seasonal variability and changes due to the flushing of the plume from the wetland system. Conclusions about tritium fluxes to the wetlands and FMB should consider the complexity of the groundwater system and should be based on long-term surface water, seepline, and groundwater monitoring data and not on quarterly changes in concentrations at seepline monitoring stations.

\section{F- and H-Area Seepline Conductivity Measurements}

\section{F Area}

Conductivity measurements in the F-Area seepline ranged from 32 to $1948 \mu \mathrm{S} / \mathrm{cm}$ (see Table 1 and Figure 8). Due to the variability of conductivity measurements, only differences of $100 \mu \mathrm{S} / \mathrm{cm}$ or more are considered significant. Of the 21 locations sampled at the F-Area seepline, four had measurements of more than $100 \mu \mathrm{S} / \mathrm{cm}$ above the 1989 measurements. A comparison of the graphs in Figures 6 and 8 suggests that conductivity follows the same general 
trends as the tritium activities. Using a Spearman rank correlation test for nonparametric data, it was found that the probability that tritium and conductivity exhibited independent trends was $P<0.000$. The rank correlation coefficient was found to be rs $=0.90$, suggesting that the two parameters exhibit the same trends. This similarity is expected because tritium traces the movement of the contaminant plume from the basins (Haselow et al., 1990).

\section{H Area}

Conductivity measurements in the $\mathrm{H}$-Area seepline ranged from 65 to $685 \mu \mathrm{S} / \mathrm{cm}$ (see Table 2 and Figure 9). Of the 22 sampling locations, only two had measurements of more than $100 \mu \mathrm{S} / \mathrm{cm}$ above the 1989 measurements. Data in Figures 4 and 6 suggest that conductivity and tritium are following the same general trends. The Spearman rank correlation test for nonparametric data was used to investigate the correlation of H-Area tritium activities and conductivity values. The probability that the two parameters exhibited independent trends is $\mathrm{P}<0.006$. The rank correlation coefficient ( $r s=0.54$ ) for $\mathrm{H}$ Area was lower than that for F Area, but still suggested a good correlation.

\section{$\mathrm{F}$ - and $\mathrm{H}$-Area Seepline $\mathrm{pH}$ Measurements}

F-Area pH values ranged from 3.6 to 6.0 with an average value of 5.0 (Table I and Figure 10). H-Area $\mathrm{pH}$ values ranged from 4.9 to 6.5 with an average of 5.7 (see Table 2 and Figure 11). The $\mathrm{pH}$ for the entire seepline (F and $\mathrm{H}$ Areas combined) averaged 5.3. The average increased 0.4 units (a threefold increase) over the 4.9 average in 1989 (Haselow et al., 1990). In each of the past five surveys, the decrease in hydrogen ion concentration ranged from fourto fivefold compared to 1989 measurements. The increase in $\mathrm{pH}$ will affect the solubility of metals in the soil, which will enhance the recovery of wetlands potentially stressed indirectly by low $\mathrm{pH}$. Aluminum concentrations measured along the seepline in 1989 (Haselow et al., 1990) were high enough to be potentially toxic to plants. Increases in $\mathrm{pH}$ (to about neutral) will reduce the solubility of aluminum and thereby reduce this as a possible source of plant toxicity. Concentrations of aluminum and other metals measured along the seepline in July 1992 were substantially lower than 1989 concentrations, reflecting the increase in pH (Dixon and Rogers, 1993e). Field observations revealed that vegetation in most of the stressed areas is recovering.

\section{Fourmile Branch Measurements}

Figures 12 through 14 illustrate the tritium, conductivity, and $\mathrm{pH}$ values for the Fourmile Branch (FMB) sampling locations. Table 3 provides the data for the figures. Tritium activities at these locations ranged from 41 to $503 \mathrm{pCi} / \mathrm{ml}$.
Conductivity measurements ranged from 75 to $93 \mu \mathrm{S} / \mathrm{cm}$ and $\mathrm{pH}$ ranged from 6.18 to 6.22 . The conductivity and the $\mathrm{pH}$ values were at near normal levels.

\section{Solid Waste Disposal Facility (643-E) Seepline Measurements}

Figures 15 through 17 illustrate tritium, conductivity, and $\mathrm{pH}$ values for the seepline and stream sampling locations south of 643-E, which is part of the Solid Waste Disposal Facility (Table 4 provides the data used in the figures). This seepline is along the natural drainage (old F-Area effluent ditch) that was used to discharge effluent from F-Area separations prior to construction of the engineered effluent canal.

Tritium activities for the locations on the east side of the drainage ranged from 35 to $947 \mathrm{pCi} / \mathrm{ml}$. Activities on the west side of the drainage ranged from 169 to $59,400 \mathrm{pCi} / \mathrm{ml}$. The tritium activity at the stream location in the drainage (FHB012) was $17,100 \mathrm{pCi} / \mathrm{ml}$.

Conductivity measurements on both sides of the drainage were near background at most locations and ranged from 25 to $428 \mu \mathrm{S} / \mathrm{cm}$. Some locations exhibited elevated conductivity values; however, these values are typical of the conductivity values typically reported in the water table wells in the vicinity of the old F-Area effluent ditch (EMS, 1993). Using the Spearman rank correlation test, no correlation $(\mathrm{r}=-0.19)$ was found between conductivity and tritium for these locations. $\mathrm{pH}$ values ranged from 4.8 to 6.7 with an average of 5.2.

These results are consistent with the Haselow et al. (1990) results for the western portion of the H-Area seepline, particularly near location HSP103. Haselow et al. (1990) found that down gradient from $643-\mathrm{E}$, conductivity values were near background while tritium concentrations were elevated. This was attributed to tritiated wastes deposited in 643-E. Tritium activities measured along the seepline down gradient of $643-\mathrm{E}$ (particularly those on the west side) suggest that tritium migrating from $643-\mathrm{E}$ and outcropping in this area is substantial. The appearance of tritium on the west side as opposed to the east side of the drainage suggests that soil material placed in the northern reaches of the natural drainage is impacting the local hydrology. It appears that the groundwater and tritium are moving below the fill material and outcropping on the west side of the drainage. The results suggest that the sampling locations on the west side of the drainage have delineated the tritium outcrop area with the center located at or near FHB018. 


\section{Conclusions}

Tritium concentrations measured at most locations in September 1993 increased or remained relatively unchanged, compared to previous sampling events. These results contrast those from previous sampling events and are attributed to the dynamic nature of the tritium plume movement. Below-normal rainfall caused the toe of the tritium plume to migrate toward the seepline intercept and away from FMB. This produced a seasonal increase in tritium concentrations, as measured at the seepline. Total tritium fluxes to the wetlands and FMB steadily declined since the basin closure (Looney et al., 1993) and overall results from the tritium survey support this finding. These findings support the hypothesis that the tritium plume in F- and H-Area is being flushed from the shallow groundwater. Differences in tritium concentrations measured at seepline sampling locations from one sampling event to the next represent seasonal variability and changes due to flushing the contaminant plume from the wetland system. Conclusions about tritium fluxes to the wetlands and FMB should consider the complexity of the groundwater system and should be based on long-term surface water, seepline, and groundwater monitoring data, not on quarterly changes in concentrations at seepline monitoring stations.

Evaluation of data from several seepline locations south of the 643-E facility indicates that tritium migrating from 643-E is outcropping at the old F-Area effluent ditch, particularly on the west side. It appears that sampling locations on the west side of the ditch delineated the tritium outcrop area.

\section{References}

Daniel, W. W. 1978. Applied Nonparametric Statistics. Houghton Mifflin Company, Boston, MA.

'Dixon, K. L. and V. A. Rogers. 1992. Results of the First Quarter Tritium Survey of the F- and H-Area Seeplines: May 1992. WSRC-TR-92-304, Westinghouse Savannah River Company, Savannah River Technology Center, Aiken, SC.

Dixon, K. L. and V. A. Rogers. 1993a. Results of the Second Quarter Tritium Survey of the F- and H-Area Seeplines: September 1992. WSRC-TR-93-129, Westinghouse Savannah River Company, Savannah River Technology Center, Aiken, SC.

Dixon, K. L. and V. A. Rogers. 1993b. Results of the Third Quarter Tritium Survey of the $F$ - and H-Area Seeplines: December 1992. WSRC-TR-93-284, Westinghouse Savannah River Company, Savannah River Technology Center, Aiken, SC.
Dixon, K. L. and V. A. Rogers. 1993c. Results of the Fourth Quarter Tritium Survey of the F-and H-Area Seeplines: March/April 1993. WSRC-TR-93-526, Westinghouse Savannah River Company, Savannah River Technology Center, Aiken, SC.

Dixon, K. L. and V. A. Rogers. 1993d. Results of the Quarterly Tritium Survey of Fourmile Branch and Its Seeplines in the F-and H-Areas of SRS: June 1993. WSRC-TR-93-656, Westinghouse Savannah River Company, Savannah River Technology Center, Aiken, $\mathrm{SC}$.

Dixon, K. L. and V. A. Rogers. 1993e. Semi-Annual Sampling of Fourmile Branch and Its Seeplines in the $F$ and H Areas of SRS: July 1992. WSRC-TR-93-289, Westinghouse Savannah River Company, Savannah River Technology Center, Aiken, SC.

Environmental Monitoring Section. 1993. The Savannah River Site's Groundwater Monitoring Program, Second Quarter Report. ESH-EMS-930097, Westinghouse Savannah River Company, Aiken SC.

Fenimore, J. W. and J. H. Horton. 1972. Rating History and Environmental Effects of Seepage Basins in Chemical Separations Areas of the Savannah River Plant. DPST-72-548, E. I. du Pont de Nemours and Company, Savannah River Laboratory, Aiken, SC.

Haselow, J. S., M. Harris, B. B. Looney, N. V. Halverson, and J. B. Gladden. 1990. Analysis of Soil and Water at the Fourmile Branch Seepline Near the $F$ and $H$ Area of SRS $(U)$. WSRC-RP-90-0591, WSRC-TR-92-304, Westinghouse Savannah River Company, Savannah River Technology Center. Savannah River Laboratory, Aiken, SC.

Killian, T. H., N. L. Kolb, P. Corbo, and I. W. Marine. 1985a. F-Area Seepage Basins. DPST-85-704, E. I. du Pont de Nemours and Company, Savannah River Laboratory, Aiken, SC.

Killian, T. H., N. L. Kolb, P. Corbo, and I. W. Marine. 1985b. H-Area Seepage Basins. DPST-85-706, E. I. du Pont de Nemours and Company, Savannah River Laboratory, Aiken, SC.

Looney, B. B., J. S. Haselow, C. M. Lewis, M. K. Harris, D. E. Wyatt, C. S. Hetrick. 1993. Projected Tritium Releases from $F$ and $H$ Area Seepage Basins and the Solid Waste Disposal Facilities to Fourmile Branch (U). WSRC-RP-93-459, Westinghouse Savannah River Company, Savannah River Technology Center, Aiken, SC. Savannah River Laboratory, Aiken, SC.

WSRC-3Q1-4. 1992. Determination of Tritium in Water. Procedure 2760, Rev 0. Westinghouse Savannah River Company, Aiken, SC. 
WSRC-L14.1. 1992a. Procedure for Cole-Parmer Portable Conductivity Meter Model 1481-40. Procedure 279, Rev 1. Westinghouse Savannah River Company, Aiken, SC.

WSRC-L14.1. 1992b. Procedure for Cole-Parmer Model 5985-80 pH Meter. Procedure 2-81, Rev 1. Westinghouse Savannah River Company, Aiken, SC. 


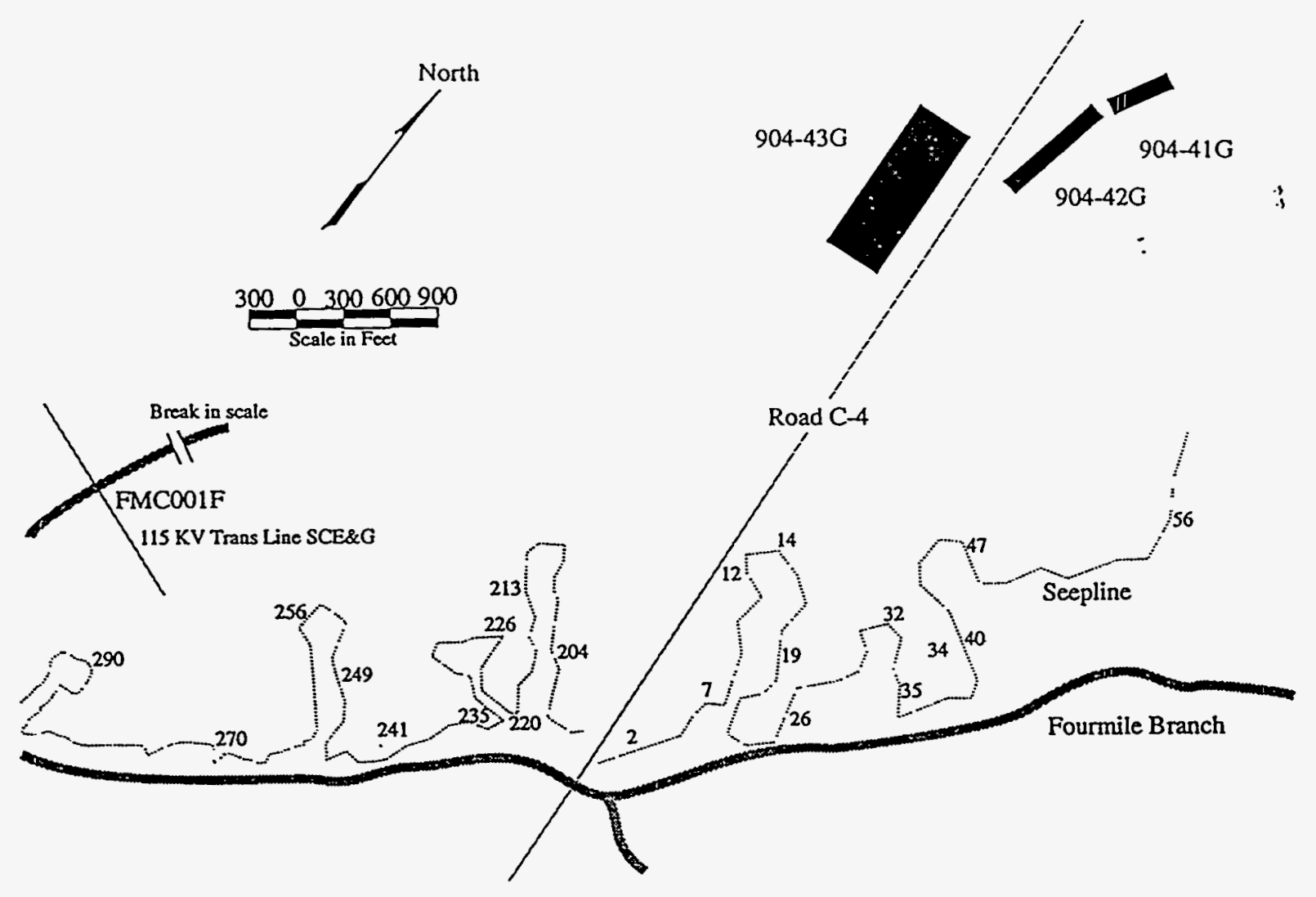

Figure 1. Location of F-Area Seepage Basins and Seepline Sampling Locations.

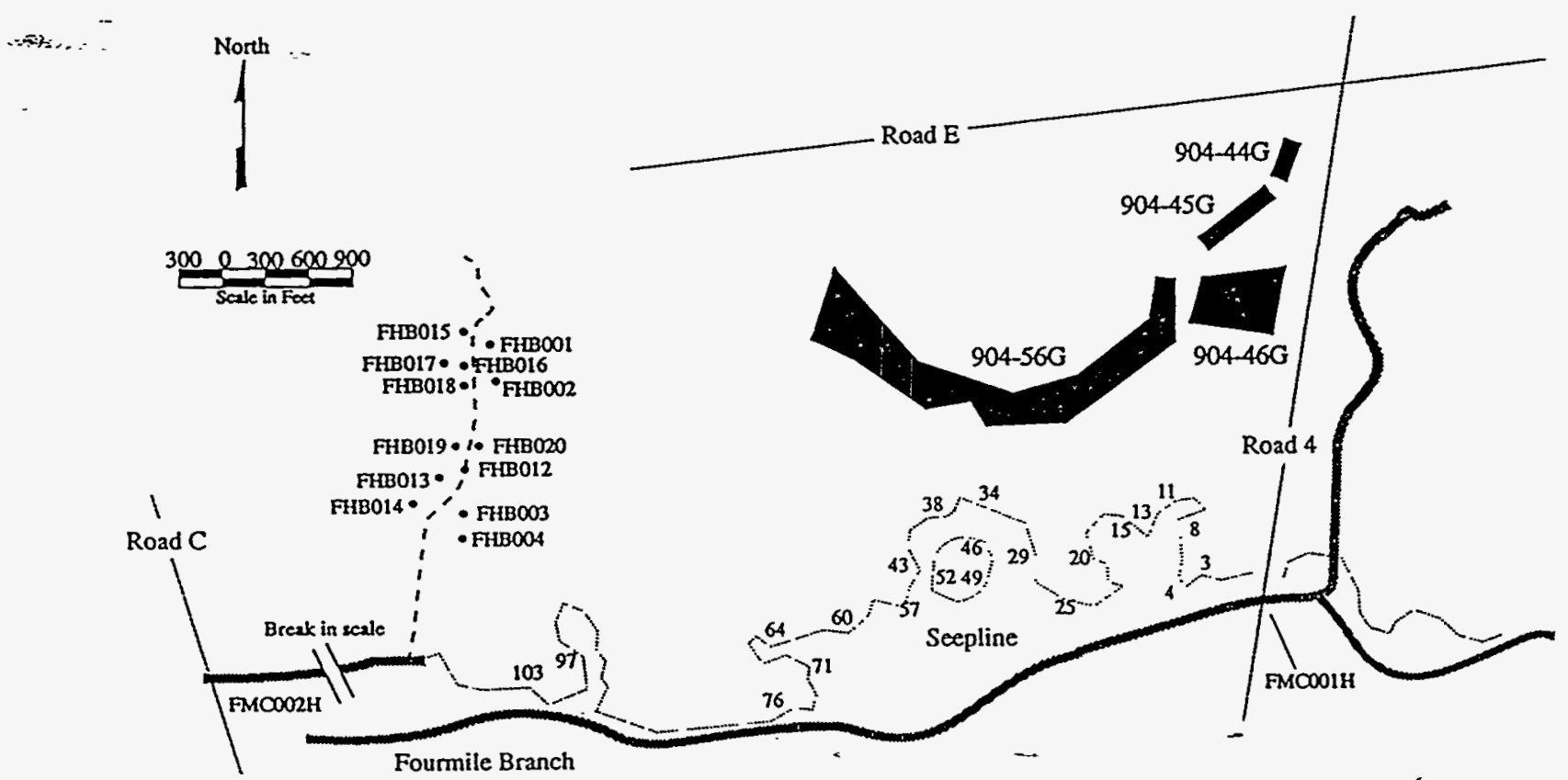

Figure 2. Location of H-Area Seepage Basins and Seepline Sampling Locations and FHB Sampling Locations 


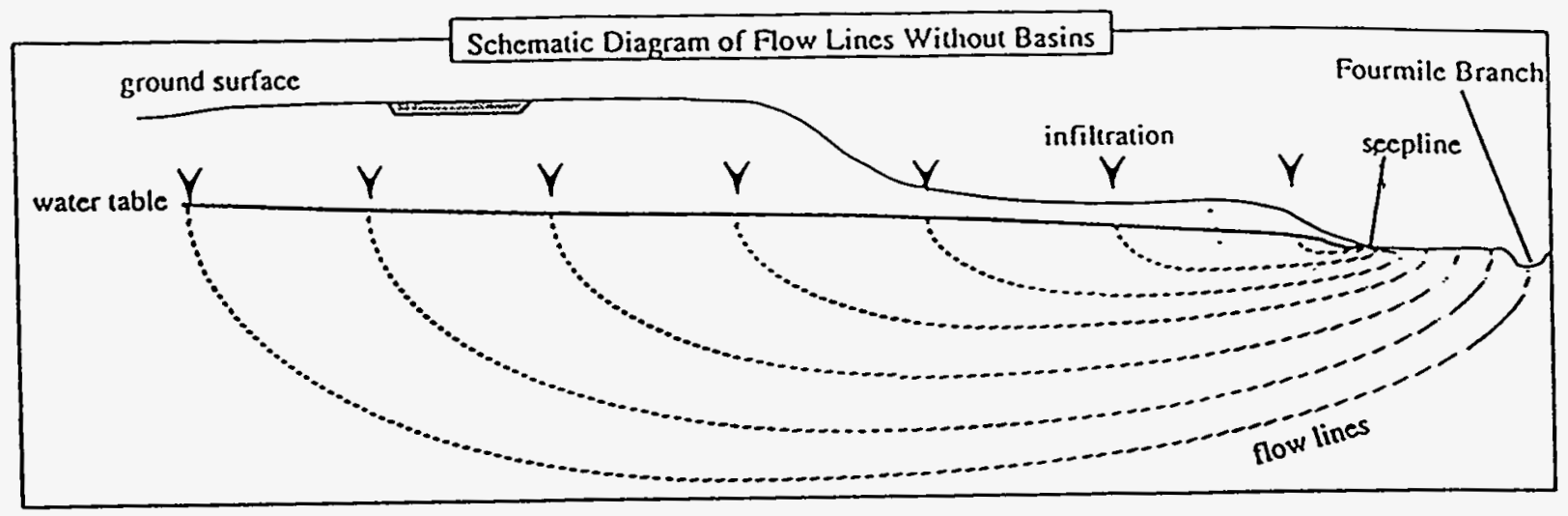

Figure 32. Schematic Diagram of Flow Lines Without Basins.

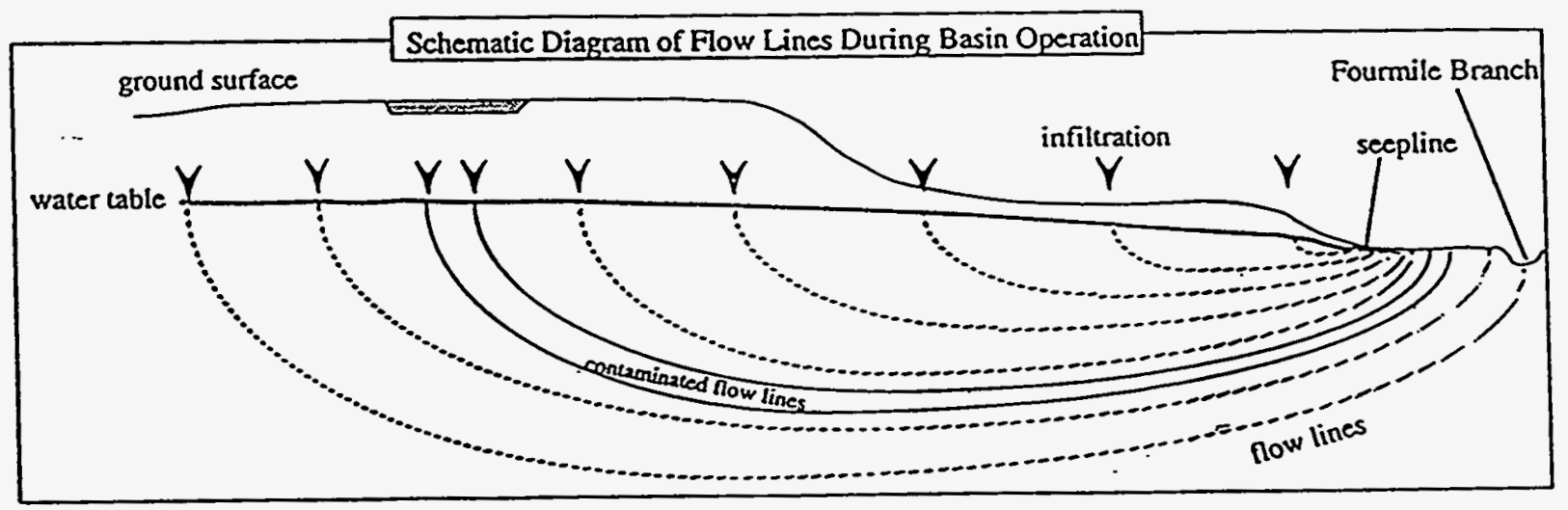

Figure 3b. Schematic Diagram of Flow Lines During Basin Operation. 


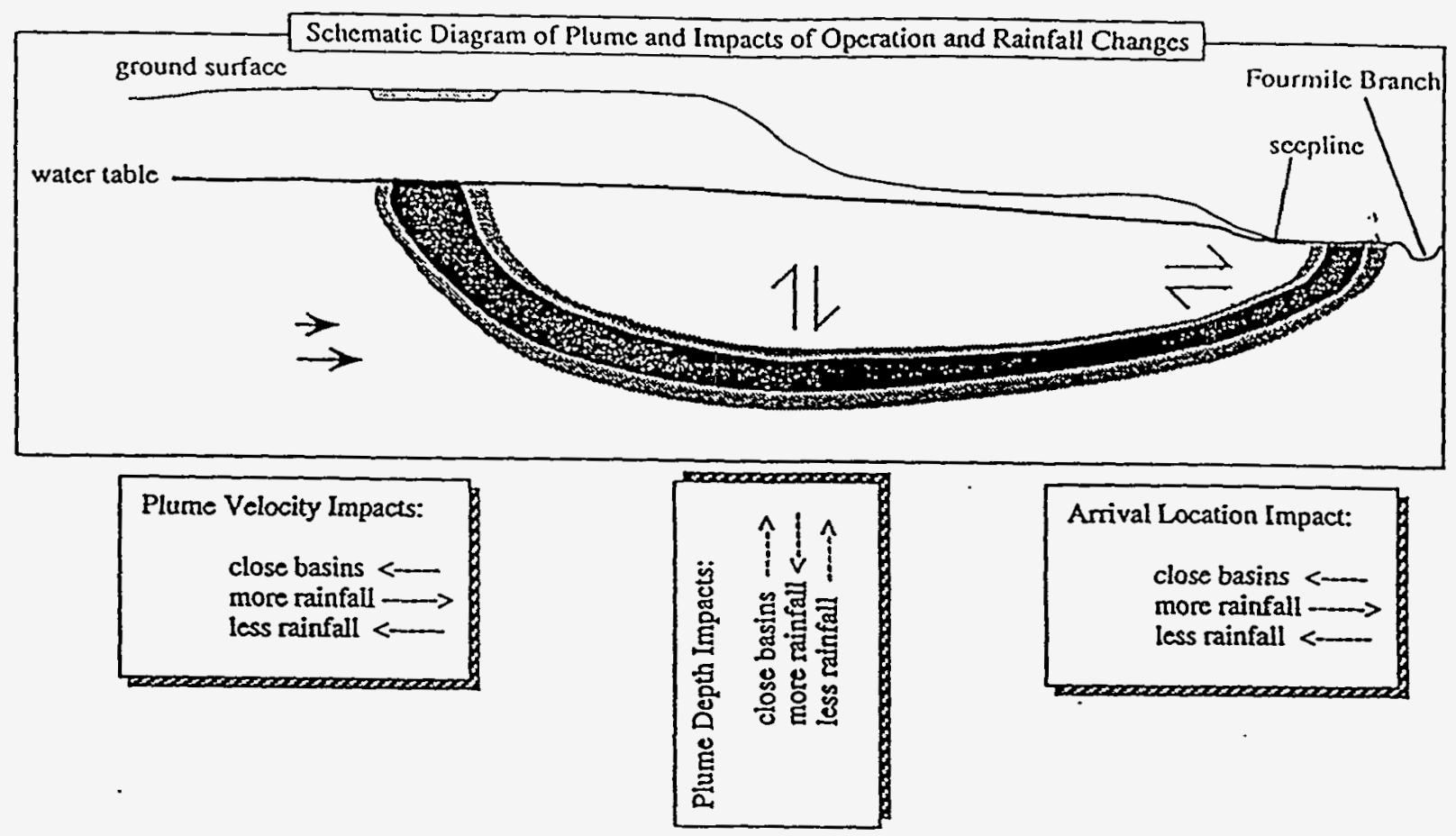

Figure 4. Schematic Diagram of Plume and Impacts of Operation and Rainfall Changes

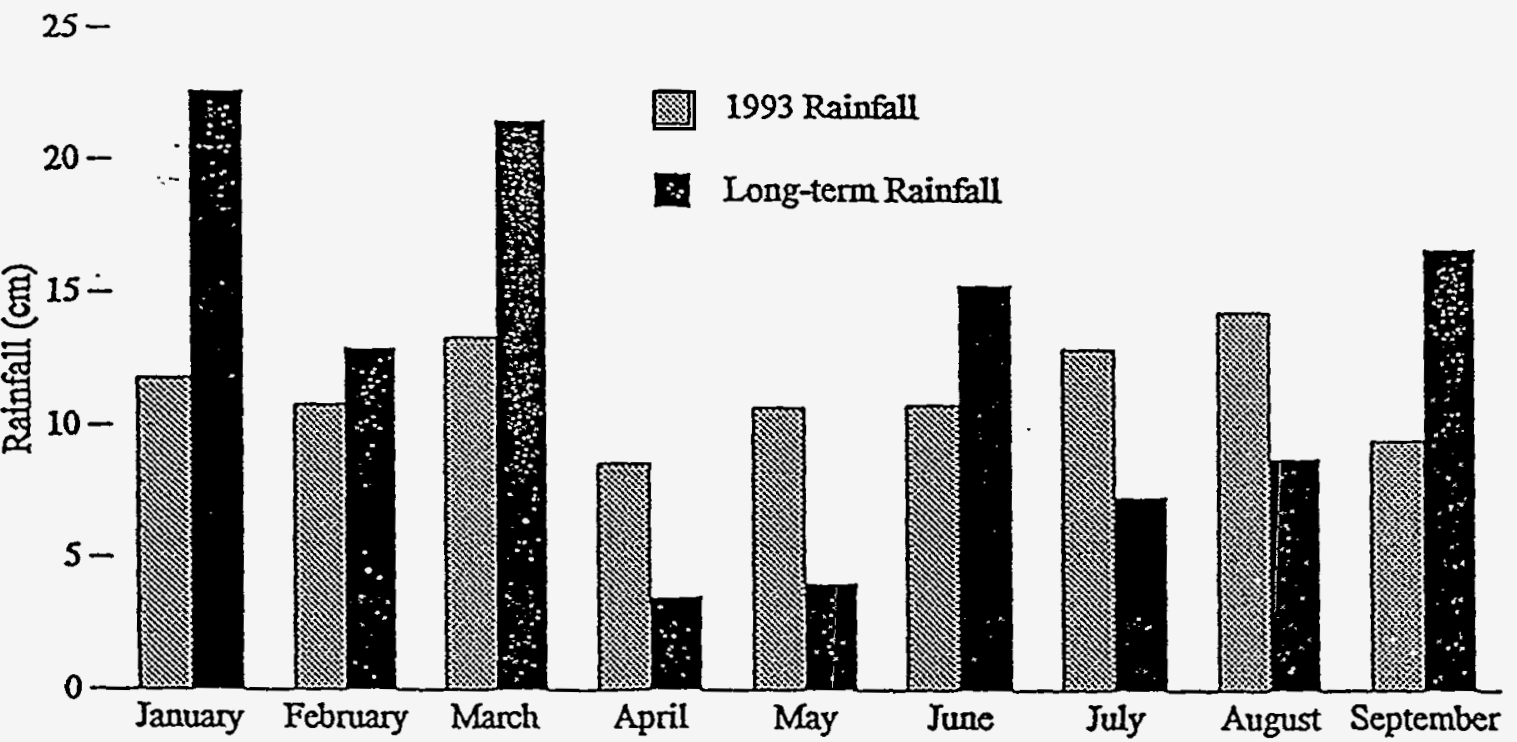

Figure 5. Comparison of 1993 Rainfall Totals to the Long-Term Average for the F-Area Weather Station from January to September. 


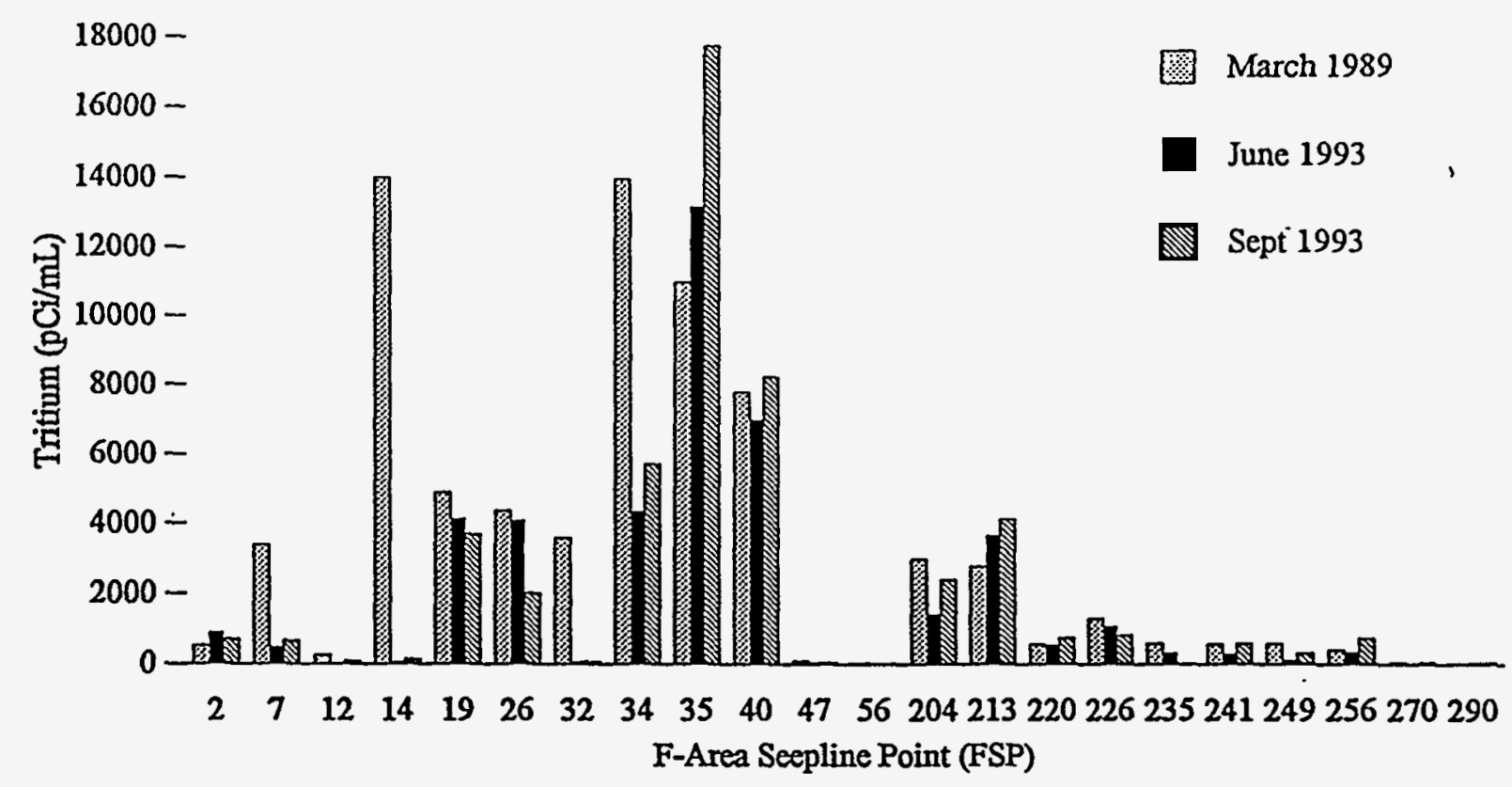

Figure 6. Comparison of March 1989, June 1993, and September 1993 Tritium Concentrations for Selected F-Area Seepline Locations.

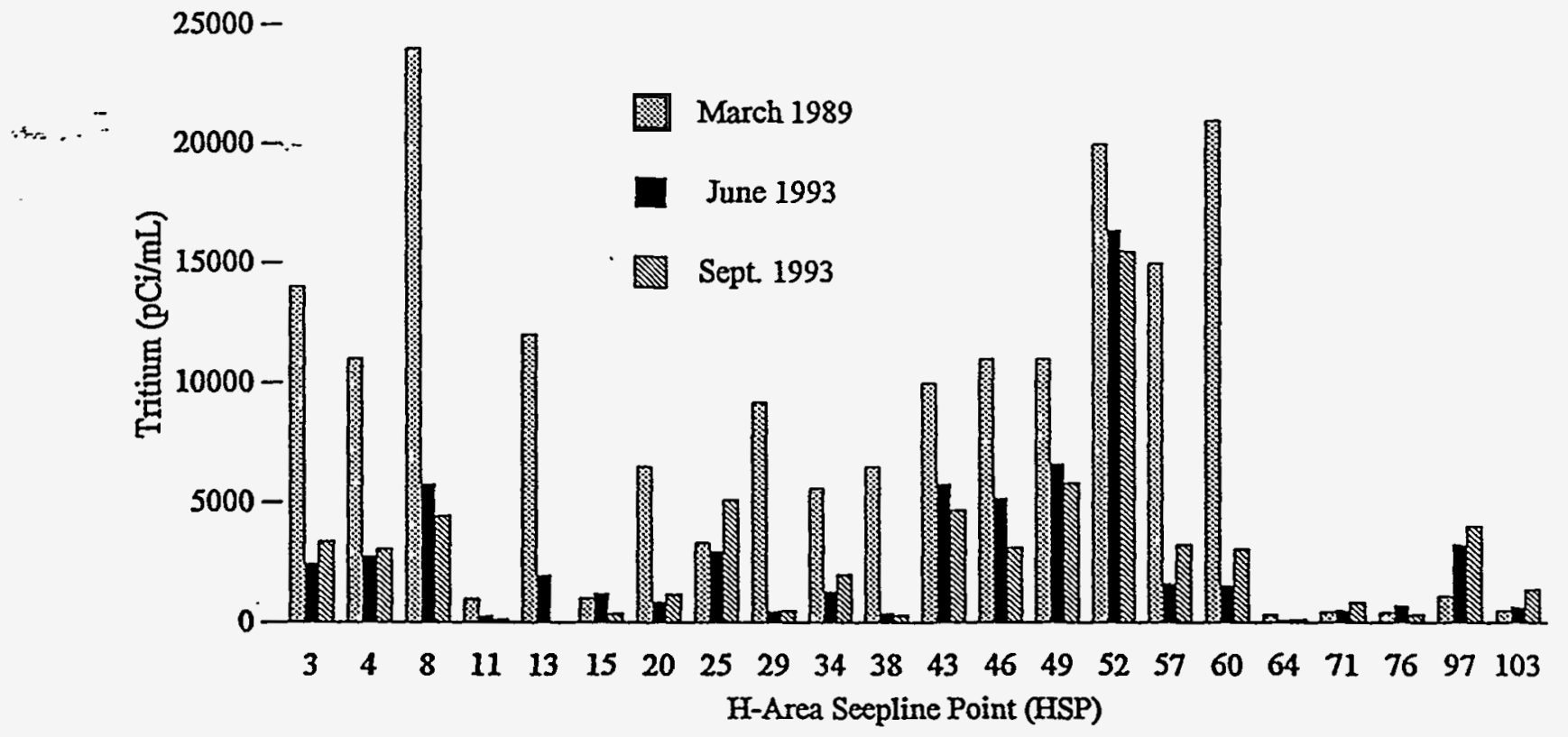

Figure 7. Comparison of March 1989, June 1993, and September 1993 Tritium Concentrations for Selected H-Area Seepline Locations. 


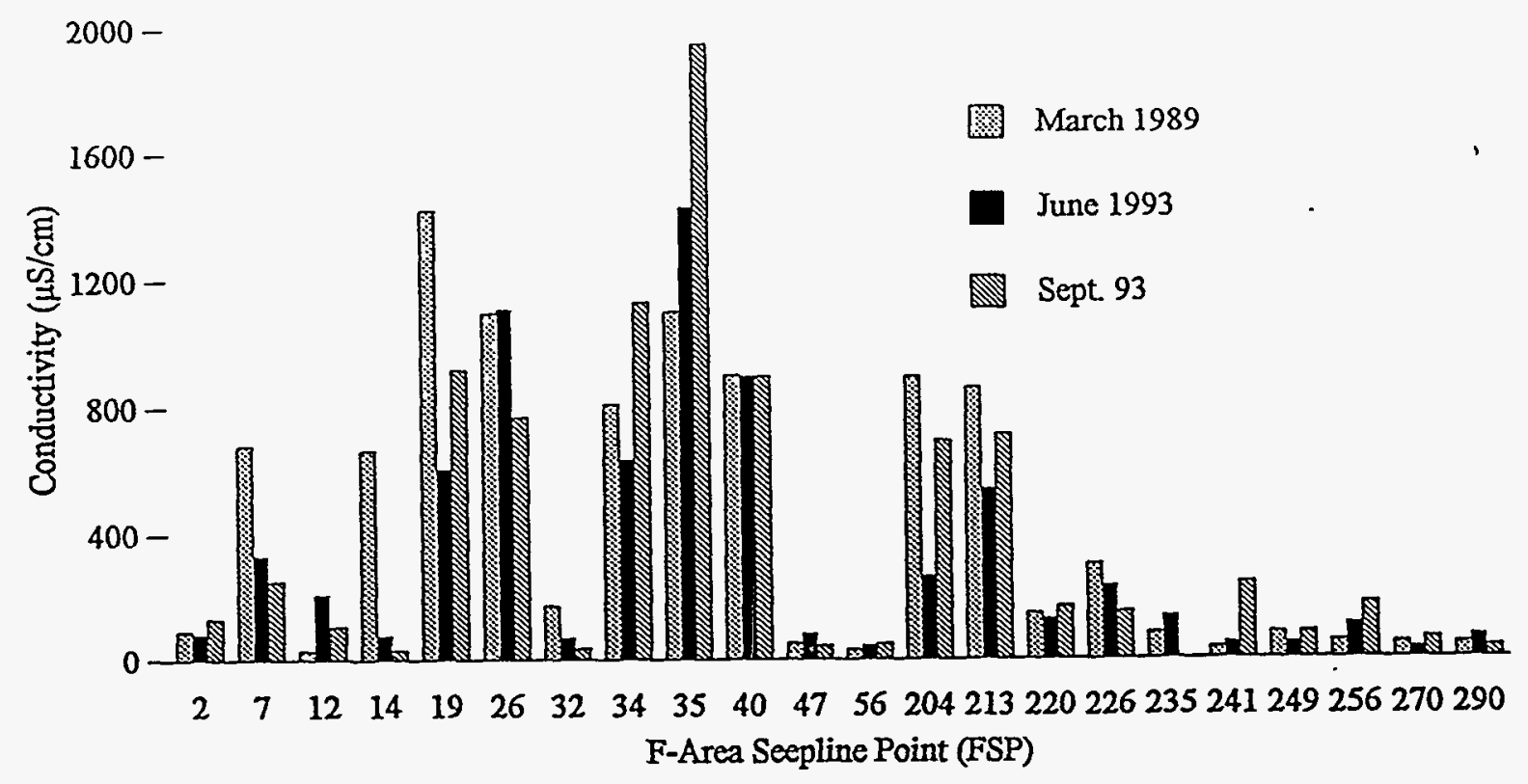

Figure 8. Comparison of March 1989, June 1993, and September 1993 Conductivity Measurements for Selected FArea Seepline Locations.

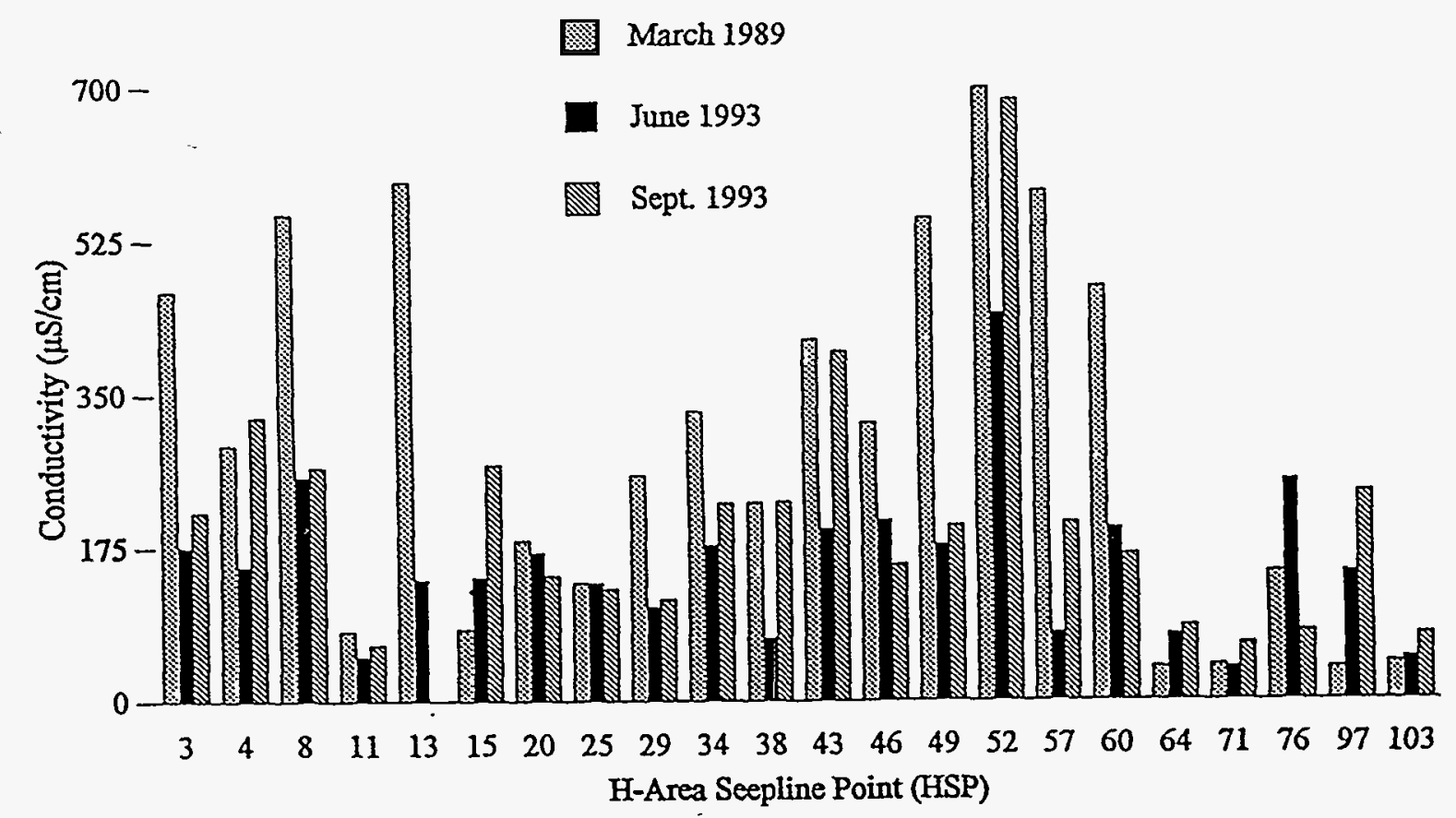

Figure 9. Comparison of March 1989, June 1993, and September 1993 Conductivity Measurements for Selected HArea Seepline Locations. 


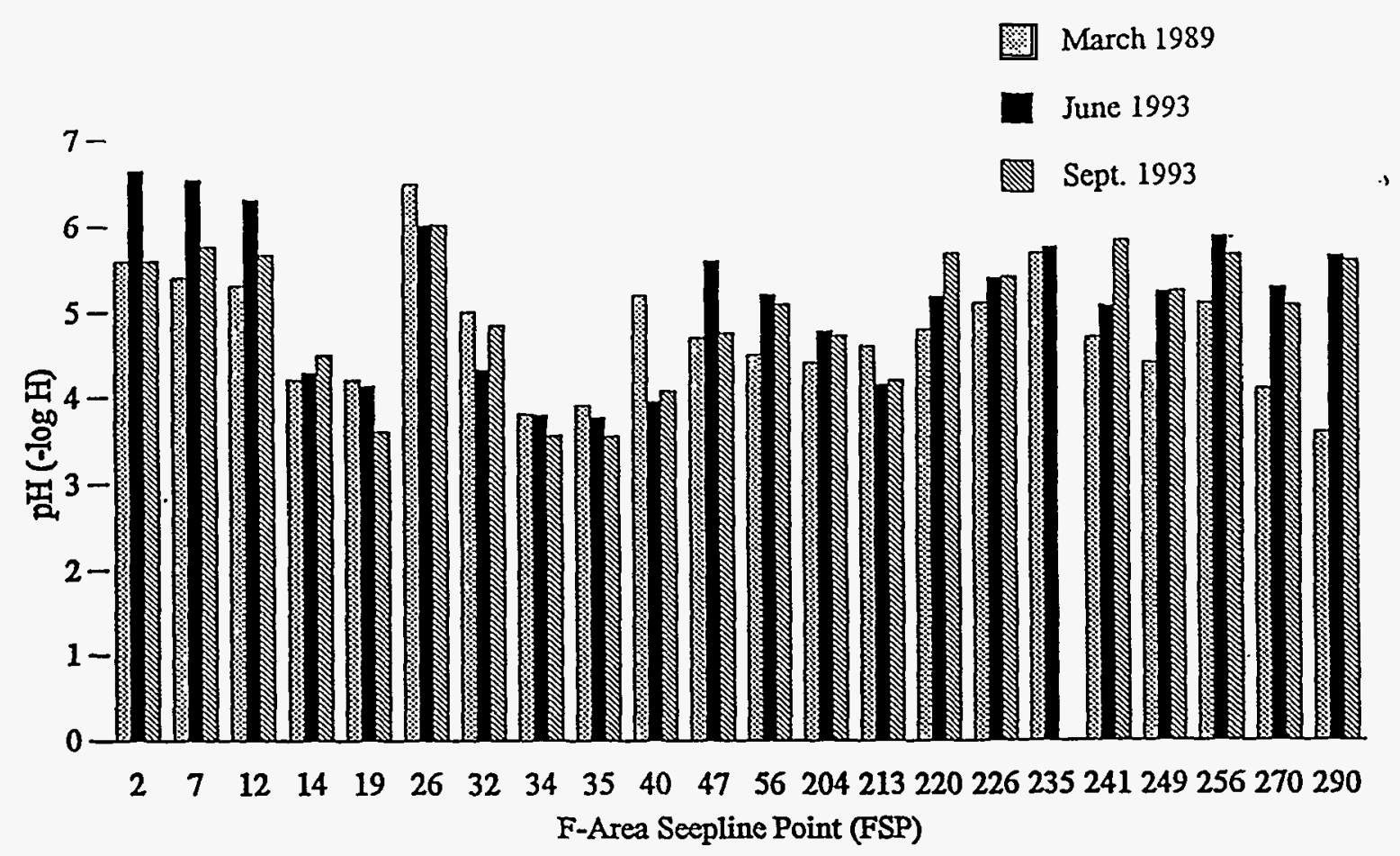

Figure 10. Comparison of March 1989, June 1993, and September $1993 \mathrm{pH}$ Measurements for Selected F-Area Seepline Locations.

March 1989

- June 1993

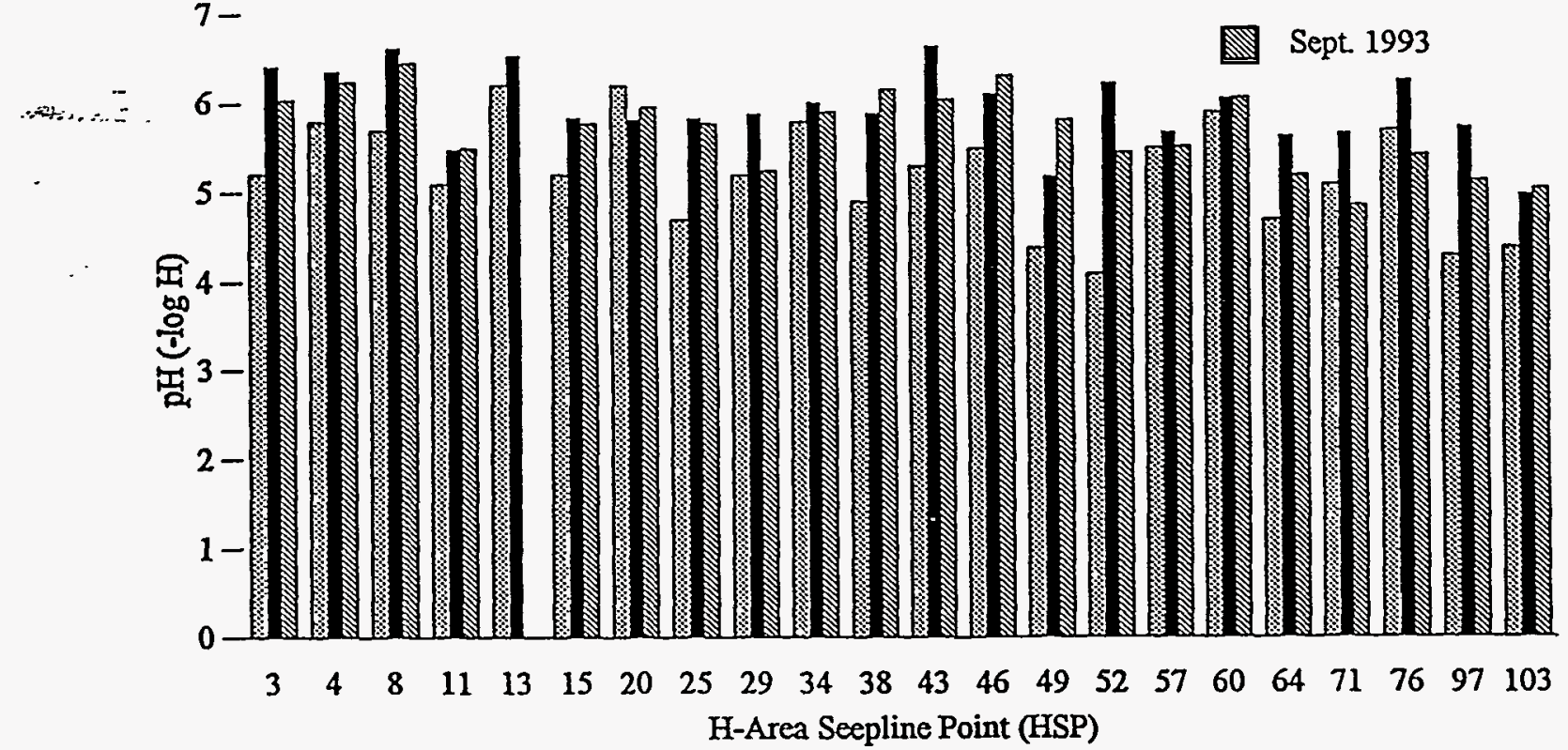

Figure 11. Comparison of March 1989, June 1993, and September $1993 \mathrm{pH}$ Measurements for Selected H-Area Seepline Locations. 


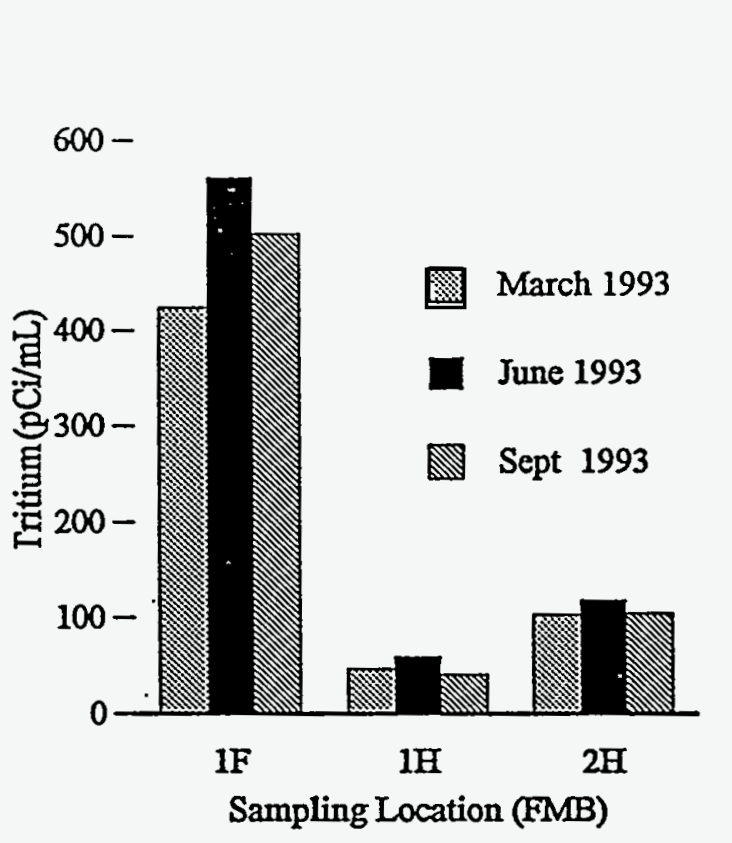

Figure 12. Comparison of March 1993, June 1993, and September 1993 Tritium Concentrations for Selected Fourmile Branch Locations.

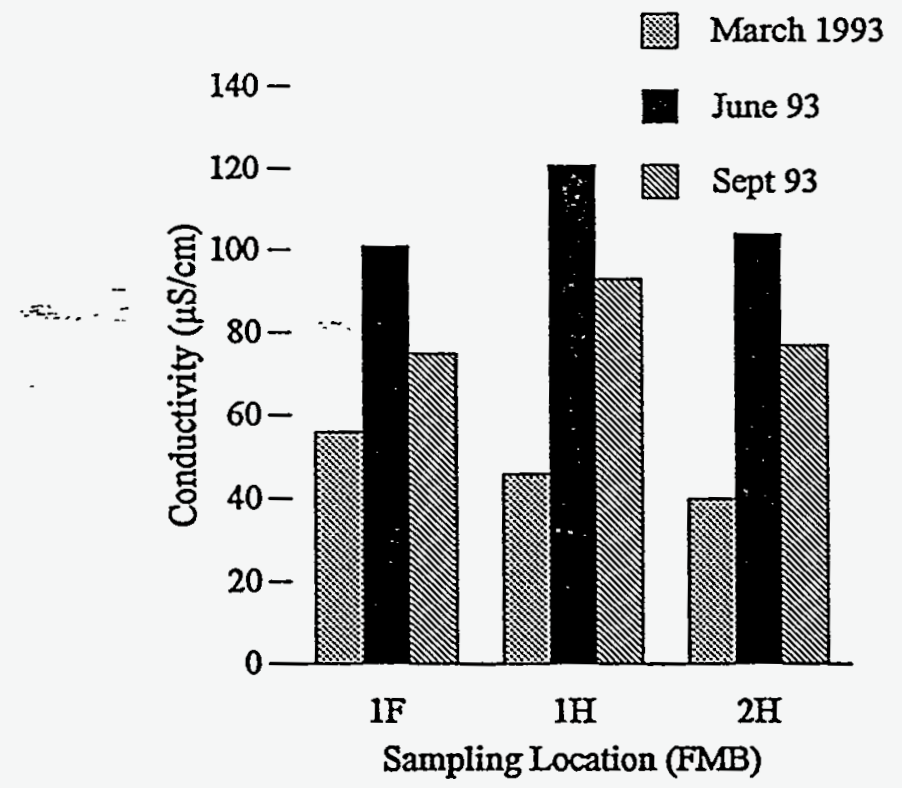

Figure 13. Comparison of March 1993, June 1993, and September 1993 Conductivity Measurements for Selected Fourmile Branch Locations.

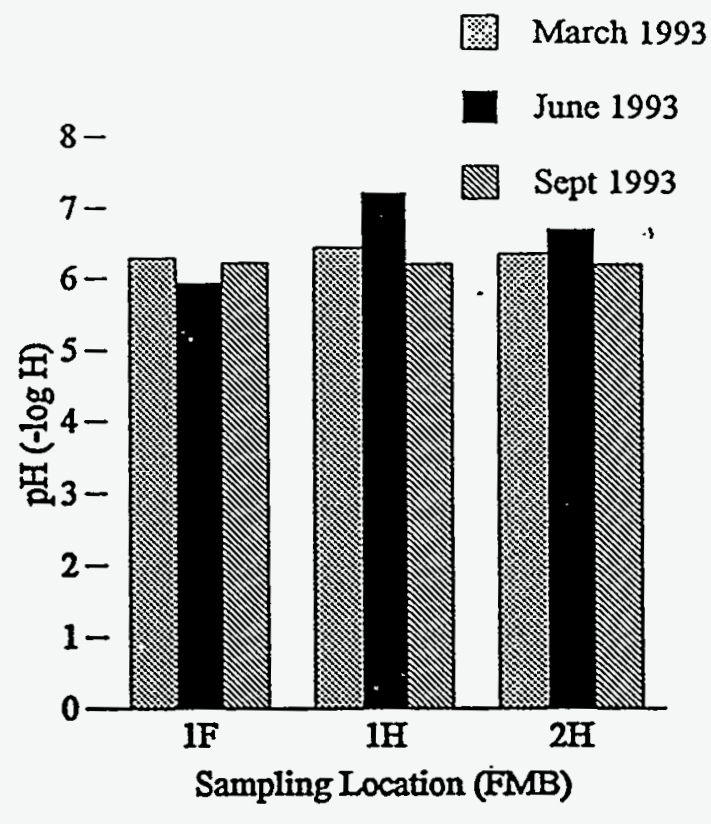

Figure 14. Comparison of March 1993, June 1993, and September $1993 \mathrm{pH}$ Measurements for Selected Fourmile Branch Locations. 


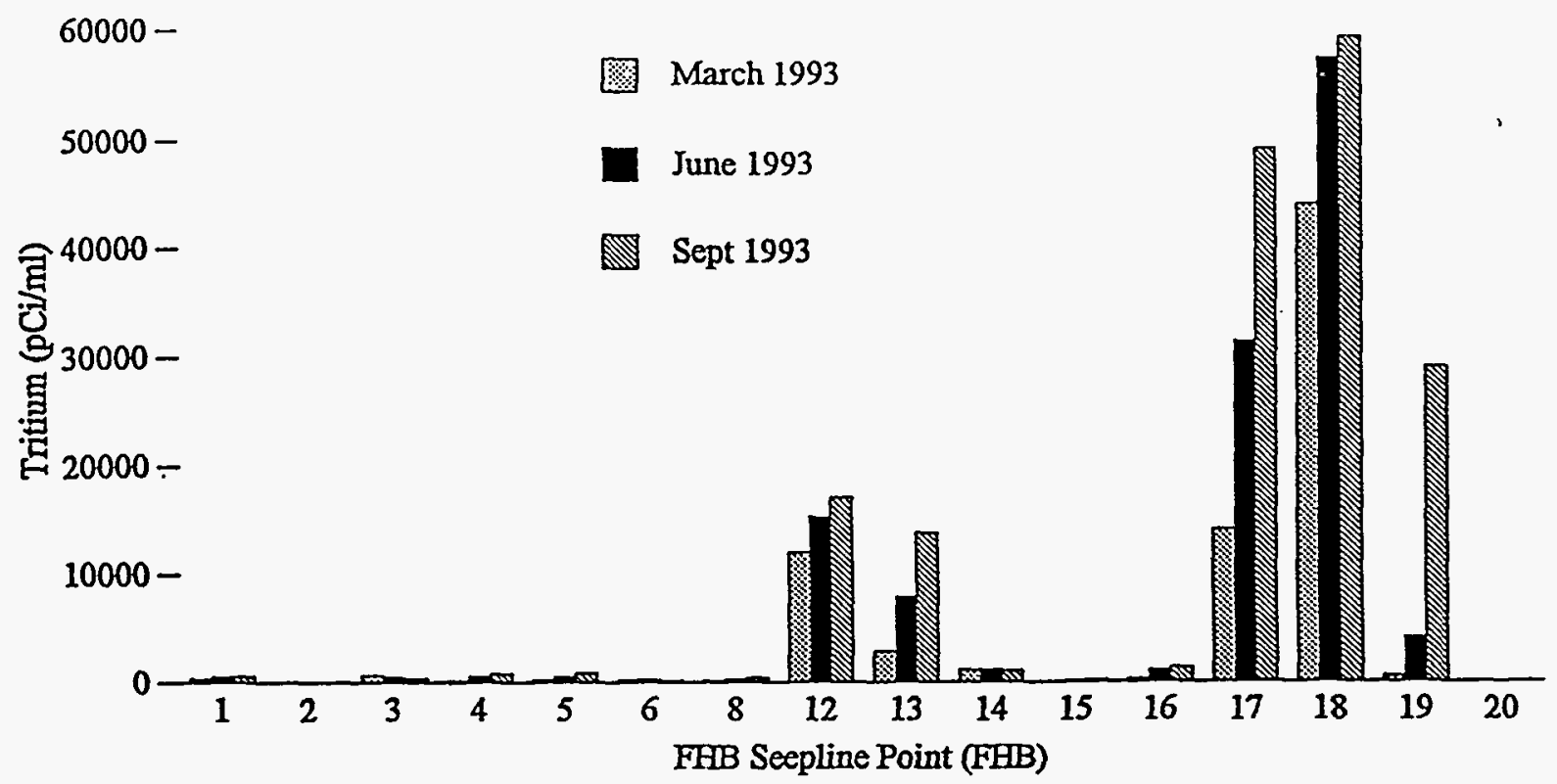

Figure 15. Comparison of March 1993, June 1993, and September 1993 Tritium Concentrations for Selected Locations on the Seepline South of 643-E.

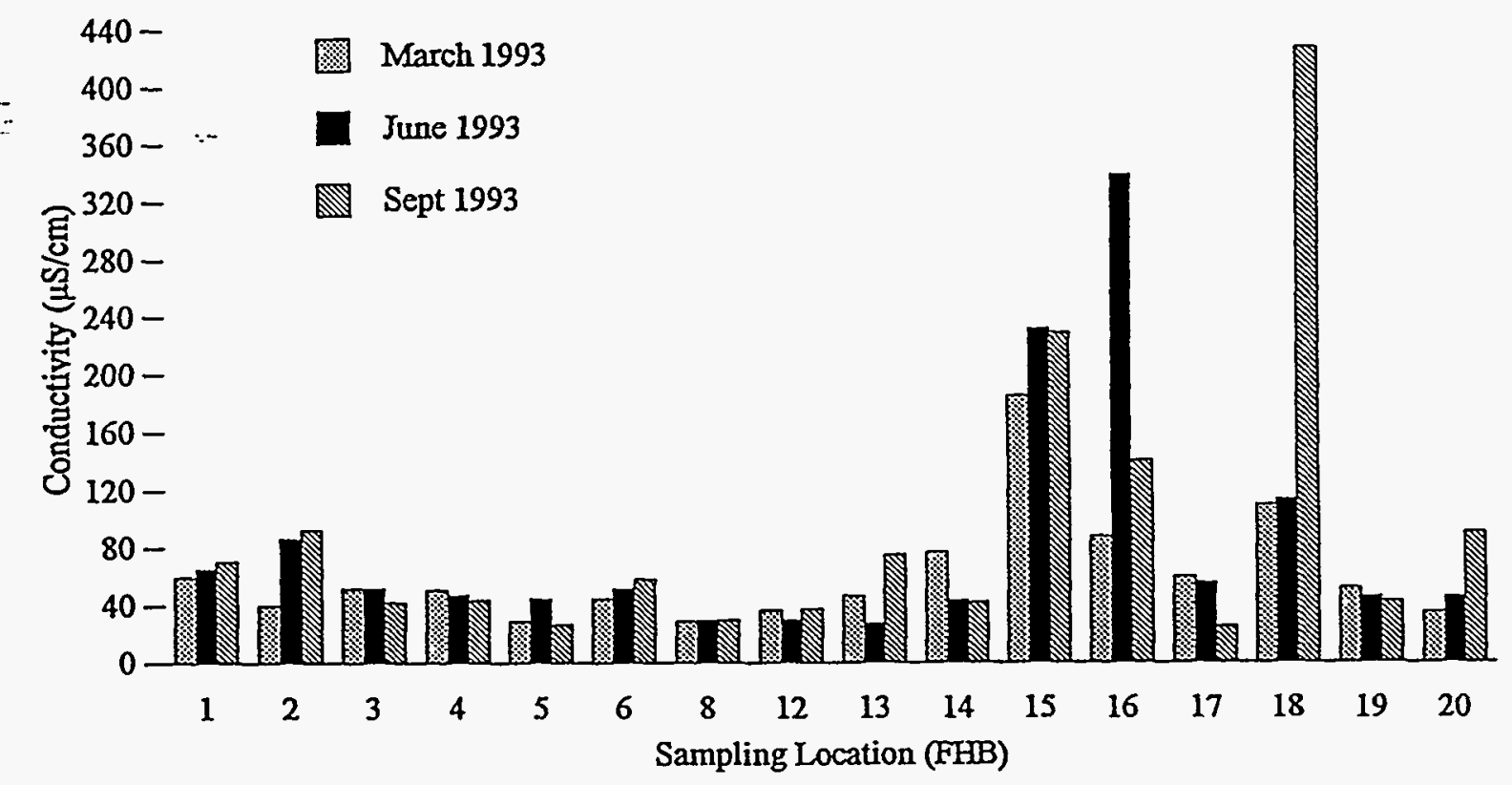

Figure 16. Comparison of March 1993, June 1993, and September 1993 Conductivity Measurements for Selected . Locations on the Seepline South of 643-E. 
March 1993

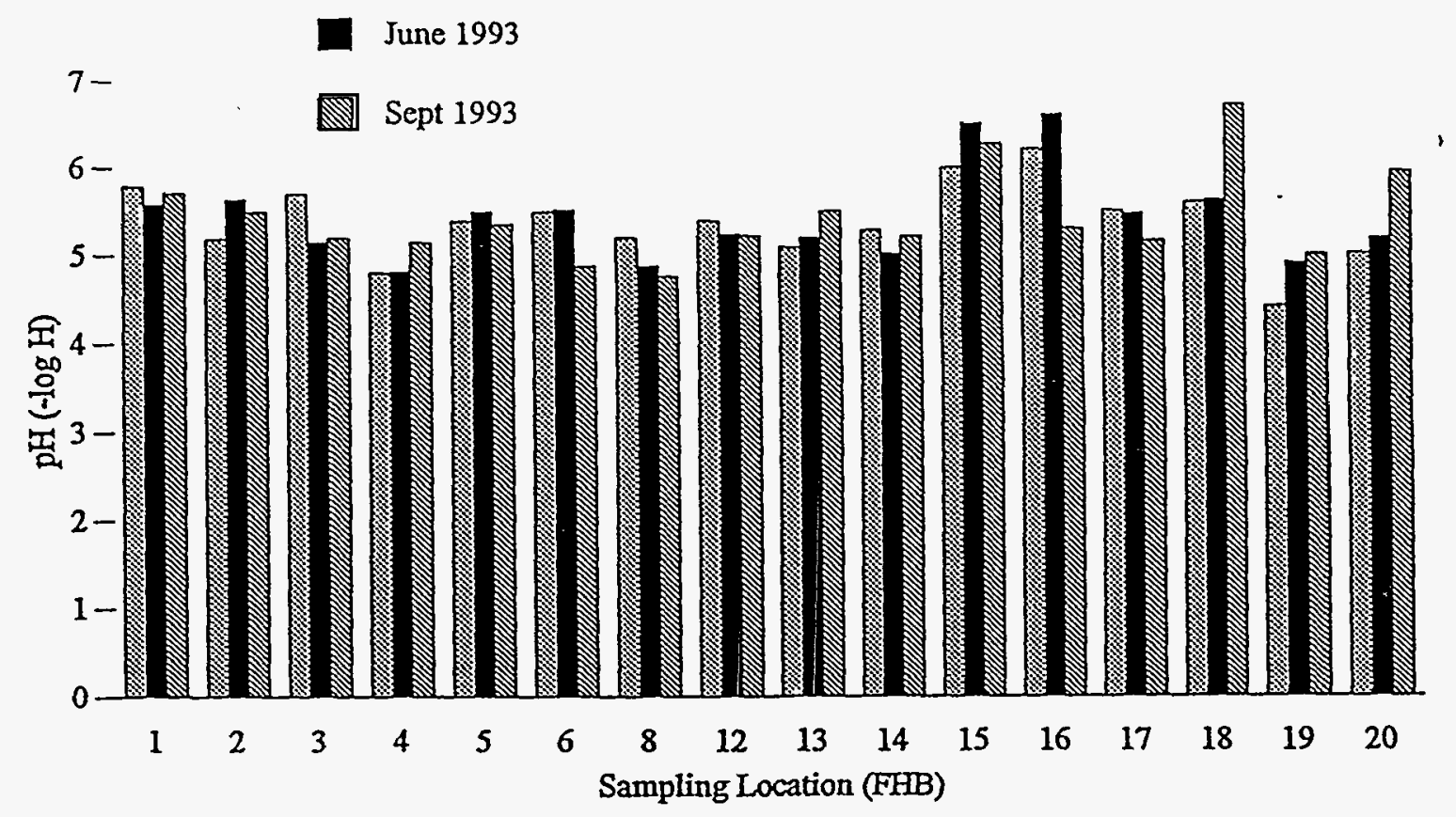

Figure 17. Comparison of March 1993, June 1993, and September $1993 \mathrm{pH}$ Measurements for Selected Locations on the Seepline South of $643-\mathrm{E}$. 
Table 1. Comparison of F-Area Seepline Measurements of Tritium, Conductivity, and pH in March 1989, June 1993, and September 1993.

\begin{tabular}{crrrrrrrrrr} 
& \multicolumn{9}{c}{ Tritium $(\mathrm{pCi} / \mathrm{ml})$} & \multicolumn{9}{c}{ Conductivity $(\mu \mathrm{S} / \mathrm{cm})$} & \multicolumn{3}{c}{$\mathrm{pH}(-\log \mathrm{H})$} \\
Location & Mar-89 & June-93 & Sept-93 & Mar-89 & June-93 & Sept-93 & Mar-89 & June-93 & Sept-93 \\
\hline 2 & 520 & 910 & 709 & 94 & 86 & 132 & 5.6 & 6.7 & 5.6 \\
7 & 3400 & 497 & 667 & 681 & 335 & 254 & 5.4 & 6.5 & 5.8 \\
12 & 260 & 29 & 91 & 30 & 212 & 108 & 5.3 & 6.3 & 5.7 \\
14 & 14000 & 76 & 134 & 666 & 81 & 32 & 4.2 & 4.3 & 4.5 \\
19 & 4900 & 4170 & 3710 & 1424 & 609 & 917 & 4.2 & 4.1 & 3.6 \\
26 & 4400 & 4110 & 2020 & 1095 & 1111 & 771 & 6.5 & 6.0 & 6.0 \\
32 & 3600 & 68 & 61 & 174 & 73 & 38 & 5.0 & 4.3 & 4.9 \\
34 & 14000 & 4380 & 5720 & 810 & 637 & 1130 & 3.8 & 3.8 & 3.6 \\
35 & 11000 & 13200 & 17800 & 1100 & 1433 & 1948 & 3.9 & 3.8 & 3.6 \\
40 & 7800 & 7020 & 8240 & 900 & 897 & 898 & 5.2 & 4.0 & 4.1 \\
47 & 100 & 53 & 38 & 52 & 86 & 45 & 4.7 & 5.6 & 4.8 \\
56 & 19 & 13 & 12 & 34 & 49 & 51 & 4.5 & 5.2 & 5.1 \\
204 & 3000 & 1450 & 2400 & 895 & 267 & 695 & 4.4 & 4.8 & 4.7 \\
213 & 2800 & 3700 & 4140 & 860 & 542 & 715 & 4.6 & 4.2 & 4.2 \\
220 & 560 & 574 & 755 & 147 & 132 & 170 & 4.8 & 5.2 & 5.7 \\
226 & 1300 & 1100 & 820 & 306 & 237 & 154 & 5.1 & 5.4 & 5.4 \\
235 & 580 & 339 & $D r y$ & 84 & 138 & Dry & 5.7 & 5.8 & Dry \\
241 & 560 & 319 & 583 & 36 & 53 & 245 & 4.7 & 5.1 & 5.9 \\
249 & 580 & 141 & 320 & 84 & 52 & 86 & 4.4 & 5.2 & 5.3 \\
256 & 400 & 374 & 736 & 56 & 113 & 179 & 5.1 & 5.9 & 5.7 \\
270 & 40 & 30 & 49 & 50 & 36 & 65 & 4.1 & 5.3 & 5.1 \\
290 & 35 & 43 & 55 & 49 & 74 & 39 & 3.6 & 5.7 & 5.6
\end{tabular}


Table 2. Comparison of H-Area Seepline Measurements of Tritium, Conductivity, and pH in March 1989, June 1993, and September 1993.

\begin{tabular}{|c|c|c|c|c|c|c|c|c|c|}
\hline \multirow[b]{2}{*}{ Location } & \multicolumn{3}{|c|}{ Tritium ( $\mathrm{pCi} / \mathrm{ml})$} & \multicolumn{3}{|c|}{ Conductivity $(\mu \mathrm{S} / \mathrm{cm})$} & \multicolumn{3}{|c|}{$\mathrm{pH}(-\log \mathrm{H})$} \\
\hline & Mar-89 & June-93 & Sept -93 & Mar-89 & June-93 & Sept-93 & Mar-89 & June-93 & Sept-93 \\
\hline 3 & 14000 & 2510 & 3380 & 468 & 177 & 216 & 5.2 & 6.4 & $\overline{6.0}$ \\
\hline 4 & 11000 & 2820 & 3060 & 292 & 155 & 325 & 5.8 & 6.4 & 6.2 \\
\hline 8 & 24000 & 5800 & 4440 & 556 & 257 & 267 & 5.7 & 6.6 & 6.5 \\
\hline 11 & 960 & 306 & 123 & 80 & 52 & 65 & 5.1 & 5.5 & 5.5 \\
\hline 13 & 12000 & 1990 & Dry & 592 & 139 & Dry & 6.2 & 6.5 & Dry \\
\hline 15 & 1000 & 1250 & 371 & 82 & 142 & 270 & 5.2 & 5.9 & 5.8 \\
\hline 20 & 6500 & 894 & 1190 & 183 & 170 & 143 & 6.2 & 5.8 & 6.0 \\
\hline 25 & 3300 & 2990 & 5120 & 135 & 135 & 128 & 4.7 & 5.8 & 5.8 \\
\hline 29 & 9200 & 498 & 510 & 257 & 109 & 116 & 5.2 & 5.9 & 5.3 \\
\hline 34 & 5600 & 1350 & 1990 & 331 & 179 & 226 & 5.8 & 6.0 & 5.9 \\
\hline 38 & 6500 & 446 & 307 & 227 & 73 & 228 & 4.9 & 5.9 & 6.2 \\
\hline 43 & 10000 & 5800 & 4680 & 413 & 197 & 399 & 5.3 & 6.7 & 6.1 \\
\hline 46 & 11000 & 5210 & 3120 & 318 & 207 & 155 & 5.5 & 6.1 & 6.3 \\
\hline 49 & 11000 & 6670 & 5850 & 551 & 179 & 200 & 4.4 & 5.2 & 5.8 \\
\hline 52 & 20000 & 16400 & 15500 & 699 & 443 & 685 & 4.1 & 6.2 & 5.5 \\
\hline 57 & 15000 & 1670 & 3250 & 581 & 78 & 203 & 5.5 & 5.7 & 5.5 \\
\hline 60 & 21000 & 1550 & 3050 & 473 & 198 & 167 & 5.9 & 6.1 & 6.1 \\
\hline 64 & 320 & 85 & 124 & 38 & 76 & 85 & 4.7 & 5.6 & $5: 2$ \\
\hline 71 & 450 & 538 & 852 & 40 & 39 & 65 & 5.1 & 5.7 & 4.9 \\
\hline 76 & 400 & 710 & 344 & 146 & 252 & 79 & 5.7 & 6.3 & 5.4 \\
\hline 97 & 1100 & 3290 & 4020 & 37 & 147 & 238 & 4.3 & 5.7 & 5.1 \\
\hline 103 & 510 & 683 & 1420 & 43 & 49 & 75 & 4.4 & 5.0 & 5.1 \\
\hline
\end{tabular}

Table 3. Comparison of Fourmile Branch Measurements of Tritium, Conductivity, and pH in March 1993, June 1993, and September 1993.

\begin{tabular}{crrrrrrrrrrr} 
& \multicolumn{3}{c}{ Tritium $(\mathrm{pCi} / \mathrm{ml})$} & \multicolumn{3}{c}{ Conductivity $(\mu \mathrm{S} / \mathrm{cm})$} & \multicolumn{3}{c}{$\mathrm{pH}(-\log \mathrm{H})$} \\
Location & Mar-93 & June-93 & Sept-93 & Mar-93 & June-93 & Sept-93 & Mar-93 & June-93 & Sept-93 \\
\hline $1 \mathrm{~F}$ & 425 & 563 & 503 & 56 & 101 & 75 & 6.3 & 5.9 & 6.2 & - \\
1H & 47 & 61 & 41 & 46 & 121 & 93 & 6.4 & 7.2 & 6.2 &. \\
$2 \mathrm{H}$ & 104 & 120 & 105 & 40 & 104 & 77 & 6.3 & 6.7 & 6.2 & -
\end{tabular}


Table 4. Comparison of Measurements of Tritium, Conductivity, and pH in March 1993, June 1993, and September 1993 for the Seepline South of 643-E.

\begin{tabular}{crrrrrrrrrr} 
& \multicolumn{3}{c}{ Tritium (pCi/m) } & \multicolumn{4}{c}{ Conductivity $(\mu \mathrm{S} / \mathrm{cm})$} & \multicolumn{3}{c}{$\mathrm{pH}(-\log \mathrm{H})$} \\
Location & Mar-89 & June-93 & Sept-93 & Mar-89 & June-93 & Sept-93 & Mar-89 & June-93 & Sept-93 \\
\hline 1 & 387 & 639 & 598 & 60 & 66 & 71 & 5.8 & 5.6 & 5.7 \\
2 & 37 & 30 & 35 & 40 & 87 & 93 & 5.2 & 5.7 & 5.5 \\
3 & 682 & 563 & 408 & 52 & 52 & 42 & 5.7 & 5.2 & 5.2 \\
4 & 175 & 596 & 853 & 51 & 48 & 44 & 4.8 & 4.8 & 5.2 \\
5 & 263 & 585 & 947 & 29 & 45 & 27 & 5.4 & 5.5 & 5.4 \\
6 & 217 & 346 & 190 & 45 & 52 & 59 & 5.5 & 5.5 & 4.9 \\
8 & 134 & 316 & 432 & 29 & 30 & 30 & 5.2 & 4.9 & 4.8 \\
12 & 12000 & 15300 & 17100 & 37 & 30 & 38 & 5.4 & 5.3 & 5.2 \\
13 & 2860 & 7920 & 13800 & 47 & 28 & 76 & 5.1 & 5.2 & 5.5 \\
14 & 1150 & 1230 & 1090 & 77 & 44 & 42 & 5.3 & 5.0 & 5.2 \\
15 & 29 & 91 & 169 & 185 & 232 & 229 & 6.0 & 6.5 & 6.3 \\
16 & 306 & 1140 & 1360 & 88 & 339 & 140 & 6.2 & 6.6 & 5.3 \\
17 & 14100 & 31400 & 49200 & 60 & 56 & 25 & 5.5 & 5.5 & 5.2 \\
18 & 44000 & 57500 & 59400 & 110 & 114 & 428 & 5.6 & 5.6 & 6.7 \\
19 & 546 & 4170 & 29100 & 52 & 46 & 43 & 4.4 & 4.9 & 5.0 \\
20 & 38 & 40 & 95 & 35 & 46 & 91 & 5.0 & 5.2 & 5.9 \\
& & & & & & & & &
\end{tabular}

